\title{
PENGARUH JENIS DAN TINGKAT KERAPATAN GULMA TERHADAP PERTUMBUHAN DAN PRODUKSI KEDELAI (Glycine max [L]. Merr)
}

\author{
Agatha Christia, Dad R.J.Sembodo \& Kuswanta F. Hidayat \\ Jurusan Agroteknologi Fakultas Pertanian Universitas Lampung \\ Jl. Prof. Soemantri Brojonegoro, No. 1 Bandar Lampung 35145 \\ Email : Agathachristia216@yahoo.co.id
}

\begin{abstract}
ABSTRAK
Kedelai (Glycine max [L]. Merr.)merupakan salah satu komoditas pangan utama setelah padi yang mempunyai nilai ekonomi yang cukup tinggi, yaitu sebagai sumber protein nabati bagi kebutuhan pangan manusia. Setiap tahunnya produksi kedelai mengalami penurunan, salah satunya penyebabnya adalah gulma. Kehadiran gulma dapat menyebabkan kompetisi antara gulma dan tanaman kedelai untuk mendapatkan sarana tumbuh yang sama dan jumlahnya terbatas. Jenis dan kerapatan gulma merupakan faktor penyebab terjadinya kompetisi antara gulma dan tanaman yang berpengaruh terhadap pertumbuhan dan produksi tanaman kedelai. Penelitian ini bertujuan untuk mengetahui pengaruh jenis gulma terhadap pertumbuhan dan produksi kedelai, pengaruh kerapatan gulma terhadap pertumbuhan dan produksi kedelai, serta pengaruh interaksi antara jenis dan kerapatan gulma terhadap pertumbuhan dan produksi kedelai. Penelitian ini menggunakan Rancangan Petak Berjalur (Strip Plot Design) dengan 3 kali ulangan secara faktorial.Faktor pertama adalah tiga jenis gulma yaitu Asystasia gangetica, Rottboellia exaltata, Cyperus rotundus. Faktor kedua adalah kerapatan gulma yaitu 0, 10, 20, 40, 80 tanaman/ $\mathrm{m}^{2}$. Hasil penelitian menunjukkan bahwa gulma Rottboellia exaltata menurunkan jumlah daun 9 MST, bobot kering tajuk tanaman dan jumlah polong kedelai, Cyperus rotundus menurunkan tinggi tanaman 9 MST dan bobot kering akar tanaman, dan Asystasia gangetica menurunkan terhadap tinggi tanaman 9 MST. Kerapatan 10 gulma $/ \mathrm{m}^{2}$ menekanbobot kering akar tanaman, dan kerapatan $80 \mathrm{gulma} / \mathrm{m}^{2}$ menekan jumlah daun tanaman $9 \mathrm{MST}$. Antara jenis dan kerapatan gulma hanya terjadi interaksi dalam mempengaruhi tinggi tanaman kedelai 3 MST.
\end{abstract}

Kata kunci: gulma, kedelai, kompetisi.

\section{PENDAHULUAN}

Kedelai (Glycine max [L]. Merrill.) merupakan salah satu komoditas pangan utama setelah padi dan jagung yang memiliki sifat multiguna bagi kebutuhan manusia. Hal inilah yang menyebabkan tingginya permintaan akan kedelai. Namun meningkatnya permintaan akan kedelai tidak selaras dengan produksi kedelai yang dihasilkan setiap tahun. Produksi kedelai di Indonesia pada tahun 2012 mencapai 907.031 ton. Pada tahun 2013 hingga tahun 2014 produksi kedelai nasional terus mengalami penurunan menjadi 843.153 ton dan produksi kedelai tahun 2014 mengalami penurunan menjadi 780.163 ton (Badan Pusat Statistik, 2015).

Gulma merupakan tumbuhan yang tumbuh di suatu tempat dalam waktu tertentu yang tidak dikehendaki oleh manusia. Adanya gulma dapat menimbulkan persaingan antara tanaman dengan gulma untuk mendapatkan satu atau lebih faktor tumbuh yang terbatas (cahaya, hara, dan air), sehingga dapat mengurangi kemampuan tanaman untuk tumbuh normal. Menurut Moenandir (1993), kerugian yang ditimbulkan akibat gulma di pertanaman kedelai dapat mencapai $80 \%$. Menurut Sastroutomo (1990), faktor gulma yang mempengaruhi tingkat persaingan adalah jenis gulma, tingkat kepadatan, pola pertumbuhan dan umur gulma. Perbedaan kerapatan gulma akan menentukan besarnya gangguan gulma. Pada tingkat kerapatan gulma yang rendah persaingan gulma dengan tanaman belum terjadi sehingga penurunan atau kehilangan hasil belum terlihat. Sedangkan pada saat kerapatan gulma melebihi ambang kerusakan tanaman maka kerapatan tanaman akan menurun (Sembodo, 2010).Penelitian ini bertujuan untuk mengetahui pengaruh jenis gulma terhadap pertumbuhan dan produksi kedelai, pengaruh kerapatan gulma terhadap pertumbuhan dan produksi kedelai, dan pengaruh interaksi antara jenis dan kerapatan gulma terhadap pertumbuhan dan produksi kedelai.

\section{BAHAN DAN METODE}

Penelitian ini dilaksanakan di Lampung Selatan dan Laboratorium Gulma Jurusan Agroteknologi Fakultas Pertanian Universitas Lampung.Bahan dan Alat yang digunakan yaitu benih kedelai varietas Tanggamus, gulma 
berdaun lebar (Asystasia gangetica), gulma rumput (Rottboellia exaltata), gulma teki (Cyperus rotundus), serta penggaris dan meteran.Penelitian ini dilakukan dengan menggunakan Rancangan Petak Berjalur (Strip Plot Design) dengan tiga kali ulangan. Perlakukan disusun secara faktorial, terdapat 45 petak perlakuan dengan ukuran masing-masing petak $1 \mathrm{~m} \times 2 \mathrm{~m}$ dengan jarak per petak $0,5 \mathrm{~m}$ dan jarak tanam $30 \mathrm{~cm}$ x $20 \mathrm{~cm}$. Jarak tanam gulma yang digunakan pada kerapatan 0 , $10(25 \mathrm{~cm} \times 40 \mathrm{~cm}), 20(25 \mathrm{~cm} \times 20 \mathrm{~cm}), 40(25 \mathrm{~cm} \times 10$ $\mathrm{cm}), 80(12,5 \mathrm{~cm} \mathrm{x} 10 \mathrm{~cm})$.Variabel pengamatan dalam penelitian ini adalah persentase penutupan gulma secara visual pada 3, 6 dan 9 MST dan bobot kering gulma pada 9 MST, tinggi tanaman dan jumlah daun dari 6 tanaman sampel pada saat 3,6, dan 9 MST, bobot berangkasan kering tajuk kedelai dan bobot brangkasan kering akar kedelai dari 6 tanaman sampel pada saat 7 MST, dan jumlah polong kedelai dari 6 tanaman sampel pada saat panen.

\section{HASIL DAN PEMBAHASAN}

Hasil penelitian menunjukkan bahwa terjadi interaksi antara jenis dan kerapatan gulma dalam mempengaruhi penutupan gulma pada 3,6 dan 9 MST (Tabel 1, 2, dan 3).Penutupan gulma Asystasia gangetica dan Rottboellia exaltata tidak berbeda dan lebih tinggi dibandingkan dengan penutupan Cyperus rotundus pada kerapatan 10, 20, 40 dan $80 \mathrm{gulma} / \mathrm{m}^{2}$ (Tabel 1). Pada kerapatan 0, 10, 20, 40 dan 80 gulma/ $\mathrm{m}^{2}$ gulma Asystasia gangetica, Rottboellia exaltata dan Cyperus rotundus meununjukkan kerapatan yang semakin tinggi maka akan semakin tinggi pula penutupan gulmanya. Hal ini sejalan dengan Widayat (2002), semakin tinggi kerapatan gulma maka akan semakin tinggi laju pertumbuhansehingga semakin tinggi pula laju penutupan gulmanya.

Penutupan gulma Asystasia gangetica dan Rottboellia exaltata lebih tinggi dibandingkan Cyperus rotundus pada kerapatan 20 dan 80 gulma/ $\mathrm{m}^{2}$.Penutupan Rottboellia exaltata lebih tinggi dibandingkan Asystasia gangetica dan Cyperus rotundus pada kerapatan 10 dan $40 \mathrm{gulma} / \mathrm{m}^{2}$ (Tabel 2). Menurut Sembodo (2010), tiap jenis gulma memiliki pola pertumbuhan atau habitus (perakaran, tinggi, luas kanopi, jumlah cabang dan sebagainya) dan laju pertumbuhan yang berbeda. Perbedaan tersebut ditentukan oleh faktor genetik dan lingkungan. Sifat pertumbuhan yang berbeda ini akan menentukan daya saing gulma tersebut terhadap tanaman dan lingkungan.

Tabel 3 menunjukkan bahwa penutupan Rottboellia exaltata lebih tinggi dibandingkan penutupan Asystasia gangetica dan Cyperus rotundus pada kerapatan 10 dan 20 gulma/m². Penutupan Rottboellia exaltata dan Asystasia gangetica lebih tinggi dibandingkan penutupan Cyperus rotundus pada kerapatan 40-80 gulma/ $\mathrm{m}^{2}$. Hal ini dikarenakan Cyperus rotundus tidak tahan terhadap naungan, dimana tajuk kedelai sudah menaungi gulma sehingga intensitas cahaya matahari yang diterima gulma mulai berkurang. Akibatnya aktivitas fotosintesis gulma menurun dan pertumbuhannya terhambat. Menurut Titrosoedirdjo dkk

Tabel 1. Pengaruh interaksi jenis dan tingkat kerapatan gulma terhadap persentase penutupan gulma pada 3 minggu setelah tanam (MST) (\%).

\begin{tabular}{|c|c|c|c|c|c|c|c|}
\hline \multirow{2}{*}{$\begin{array}{l}\text { Kerapatan } \\
\text { Gulma/m² }\end{array}$} & \multicolumn{3}{|c|}{ Asli } & \multicolumn{3}{|c|}{ Transformasi $\sqrt{ } \sqrt{ } \sqrt{ }(x+0,5)$} & \multirow{2}{*}{$\begin{array}{l}\text { BNT } \\
0,05\end{array}$} \\
\hline & A. gangetica & R. exaltata & C. rotundus & A. gangetica & R. exaltata & C. rotundus & \\
\hline 0 & 0,00 & 0,00 & 0,00 & $\begin{array}{c}0,92 \mathrm{e} \\
\text { (a) }\end{array}$ & $\begin{array}{c}0,92 \mathrm{e} \\
\text { (a) }\end{array}$ & $\begin{array}{c}0,92 \mathrm{e} \\
\text { (a) }\end{array}$ & \\
\hline 10 & 7,00 & 7,33 & 6,00 & $\begin{array}{c}1,28 \mathrm{~d} \\
\text { (a) }\end{array}$ & $\begin{array}{l}1,28 \mathrm{~d} \\
\text { (a) }\end{array}$ & $\begin{array}{l}1,25 \mathrm{~d} \\
\text { (b) }\end{array}$ & \\
\hline 20 & 14,33 & 14,67 & 10,67 & $\begin{array}{c}1,39 \mathrm{c} \\
\text { (a) }\end{array}$ & $\begin{array}{c}1,40 \mathrm{c} \\
\text { (a) }\end{array}$ & $\begin{array}{c}1,34 \mathrm{c} \\
\text { (b) }\end{array}$ & $(0,02)$ \\
\hline 40 & 24,00 & 25,67 & 20,33 & $\begin{array}{c}1,49 \mathrm{~b} \\
\text { (a) }\end{array}$ & $\begin{array}{c}1,50 \mathrm{~b} \\
\text { (a) }\end{array}$ & $\begin{array}{l}1,46 \mathrm{~b} \\
\text { (b) }\end{array}$ & \\
\hline 80 & 48,33 & 50,67 & 44,00 & $\begin{array}{l}1,62 \mathrm{a} \\
\text { (a) }\end{array}$ & $\begin{array}{c}1,63 \mathrm{a} \\
\text { (a) }\end{array}$ & $\begin{array}{c}1,60 \mathrm{a} \\
\text { (b) }\end{array}$ & \\
\hline BNT 0,05 & & & & & 0,03 & & \\
\hline
\end{tabular}

Keterangan : Angka yang diikuti oleh huruf yang sama tidak berbeda nyata berdasarkan uji BNT pada taraf 5\%, dengan tanpa tanda kurung untuk membandingkan antar kerapatan gulma dan (tanda kurung) untuk membandingkan antar jenis gulma. 
Tabel 2. Pengaruh interaksi jenis dan tingkat kerapatan gulma terhadap persentase penutupan gulma pada 6 minggu setelah tanam (MST) (\%).

\begin{tabular}{|c|c|c|c|c|c|c|c|}
\hline \multirow{2}{*}{$\begin{array}{l}\text { Kerapatan } \\
\text { Gulma/m² }\end{array}$} & \multicolumn{3}{|c|}{ Asli } & \multicolumn{3}{|c|}{ Transformasi $\sqrt{ } \sqrt{ }(x+0,5)$} & \multirow{2}{*}{$\begin{array}{l}\text { BNT } \\
0,05\end{array}$} \\
\hline & A. gangetica & R. exaltata & C. rotundus & A. gangetica & R. exaltata & $\overline{\text { C. rotundus }}$ & \\
\hline 0 & 0,00 & 0,00 & 0,00 & $\begin{array}{c}0,92 \mathrm{e} \\
\text { (a) }\end{array}$ & $\begin{array}{c}0,92 \mathrm{e} \\
\text { (a) }\end{array}$ & $\begin{array}{c}0,92 \mathrm{e} \\
\text { (a) }\end{array}$ & \multirow{5}{*}{$(0,01)$} \\
\hline 10 & 10,67 & 15,33 & 9,00 & $\begin{array}{c}1,34 \mathrm{~d} \\
\text { (b) }\end{array}$ & $\begin{array}{l}1,41 \mathrm{~d} \\
\text { (a) }\end{array}$ & $\begin{array}{c}1,32 \mathrm{~d} \\
\text { (c) }\end{array}$ & \\
\hline 20 & 25,33 & 26,67 & 20,33 & $\begin{array}{c}1,50 \mathrm{c} \\
\text { (a) }\end{array}$ & $\begin{array}{c}1,51 \mathrm{c} \\
\text { (a) }\end{array}$ & $\begin{array}{c}1,46 \mathrm{c} \\
\text { (b) }\end{array}$ & \\
\hline 40 & 33,67 & 36,00 & 30,00 & $\begin{array}{c}1,55 \mathrm{~b} \\
\text { (b) }\end{array}$ & $\begin{array}{l}1,57 \mathrm{~b} \\
\text { (a) }\end{array}$ & $\begin{array}{c}1,53 \mathrm{~b} \\
\text { (c) }\end{array}$ & \\
\hline 80 & 80,00 & 83,67 & 78,67 & $\begin{array}{c}1,73 \mathrm{a} \\
\text { (a) }\end{array}$ & $\begin{array}{l}1,74 \mathrm{a} \\
\text { (a) }\end{array}$ & $\begin{array}{c}1,71 \mathrm{a} \\
\text { (b) }\end{array}$ & \\
\hline BNT 0,05 & & & & & 0,01 & & \\
\hline
\end{tabular}

Tabel 3. Pengaruh interaksi jenis dan tingkat kerapatan gulma terhadap persentase penutupan gulma pada 9 minggu setelah tanam (MST) (\%).

\begin{tabular}{|c|c|c|c|c|c|c|c|}
\hline \multirow{2}{*}{$\begin{array}{l}\text { Kerapatan } \\
\text { Gulma/m² }\end{array}$} & \multicolumn{3}{|c|}{ Asli } & \multicolumn{3}{|c|}{ Transformasi $\sqrt{ } \sqrt{ }(x+0,5)$} & \multirow{2}{*}{$\begin{array}{l}\text { BNT } \\
0,05\end{array}$} \\
\hline & A. gangetica & R. exaltata & C. rotundus & A. gangetica & R. exaltata & C. rotundus & \\
\hline 0 & 0,00 & 0,00 & 0,00 & $\begin{array}{c}0,92 \mathrm{e} \\
\text { (a) }\end{array}$ & $\begin{array}{c}0,92 \mathrm{e} \\
\text { (a) }\end{array}$ & $\begin{array}{c}0,92 \mathrm{e} \\
\text { (a) }\end{array}$ & \\
\hline 10 & 22,00 & 24,00 & 21,00 & $\begin{array}{l}1,47 \mathrm{~d} \\
\text { (b) }\end{array}$ & $\begin{array}{c}1,49 \mathrm{~d} \\
\text { (a) }\end{array}$ & $\begin{array}{l}1,46 \mathrm{~d} \\
\text { (b) }\end{array}$ & \\
\hline 20 & 40,67 & 44,67 & 38,67 & $\begin{array}{l}1,59 \mathrm{c} \\
\text { (b) }\end{array}$ & $\begin{array}{l}1,61 \mathrm{c} \\
\text { (a) }\end{array}$ & $\begin{array}{l}1,58 \mathrm{c} \\
\text { (b) }\end{array}$ & $(0,01)$ \\
\hline 40 & 80,00 & 82,33 & 79,00 & $\begin{array}{c}1,73 \mathrm{~b} \\
\text { (a) }\end{array}$ & $\begin{array}{l}1,74 \mathrm{~b} \\
\text { (a) }\end{array}$ & $\begin{array}{c}1,71 \mathrm{~b} \\
\text { (b) }\end{array}$ & \\
\hline 80 & 98,33 & 99,33 & 91,00 & $\begin{array}{c}1,77 \mathrm{a} \\
\text { (a) }\end{array}$ & $\begin{array}{c}1,78 \mathrm{a} \\
\text { (a) }\end{array}$ & $\begin{array}{c}1,75 \mathrm{a} \\
\text { (b) }\end{array}$ & \\
\hline BNT 0,05 & & & & & 0,03 & & \\
\hline
\end{tabular}

Keterangan : Angka yang diikuti oleh huruf yang sama tidak berbeda nyata berdasarkan uji BNT pada taraf 5\%, dengan tanpa tanda kurung untuk membandingkan antar kerapatan gulma dan (tanda kurung) untuk membandingkan antar jenis gulma.

(1984) dalam Pasau, Yudono, dan Sykur (2008) tajuk dari tanaman yang sudah menutupi permukaan tanah/ lahan akan menekan pertumbuhan teki.

Jenis dan kerapatan gulma terjadi interaksi dalam mempengaruhi bobot kering gulma. Rottboellia exaltata memiliki bobot kering gulma tertinggi dibandingkan Asystasia gangetica dan Cyperus rotundus pada kerapatan 10, 20, 40 dan $80 \mathrm{gulma} / \mathrm{m}^{2}$ sedangkan bobot kering Asystasia gangetica dan Cyperus rotundus tidak berbeda. Bobot kering
Asystasia gangetica tidak berbeda pada kerapatan 10$40 \mathrm{gulma} / \mathrm{m}^{2}$ dan pada kerapatan $20-80 \mathrm{gulma} / \mathrm{m}^{2}$ tetapi pada kerapatan $80 \mathrm{gulma} / \mathrm{m}^{2}$ lebih tinggi dibandingkan pada kerapatan 10 gulma $/ \mathrm{m}^{2}$. Bobot kering gulma Rottboellia exaltata pada kerapatan 20-80 gulma/ $\mathrm{m}^{2}$ tidak berbedadan lebih tinggi dibandingkan pada kerapatan $10 \mathrm{gulma} / \mathrm{m}^{2}$. Bobot kering Cyperus rotundus tidak berbeda pada kerapatan 10-20 dan kerapatan $40-80$ gulma $/ \mathrm{m}^{2}$ tetapi bobot kering gulma Cyperus rotundus pada kerapatan $40-80 \mathrm{gulma} / \mathrm{m}^{2}$ 
lebih tinggi dibandingkan pada kerapatan 10-20 gulma/ $\mathrm{m}^{2}$ (Tabel 4). Menurut Arnon (1975) dalam Yunita (2012), kerapatan gulma yang rapat biasanya akan diimbangi oleh peningkatan bobot keringnya dengan seiring bertambahnya waktu. Semakin meningkatnya kerapatan gulma akan mengakibatkan peningkatan bobot kering gulma tersebut. Semakin berat suatu gulma maka pertumbuhannya semakin baik, dan tentunya daya saingnya terhadap tanaman juga semakin membaik.

Jenis dan kerapatan gulma terjadi interaksidalam mempengaruhi tinggi tanaman kedelai pada umur 3 MST (Tabel 5). Tanaman yang berkompetisi dengan Asystasia gangetica pada kerapatan 0 gulma/ $\mathrm{m}^{2}$ lebih tinggi dibandingkan pada kerapatan 80 gulma/ $\mathrm{m}^{2}$. Tanaman yang berkompetisi dengan Rottboellia exaltata memiliki tinggi yang sama pada kerapatan 0-80 gulma/ $\mathrm{m}^{2}$, dan tanaman yang berkompetisi dengan Cyperus rotundus pada kerapatan 0 dan 20 gulma $/ \mathrm{m}^{2}$ lebih tinggi dibandingkan pada kerapatan 80 gulma/ $\mathrm{m}^{2}$, tetapi tinggi tanaman pada kerapatan $0,10,40,80$ dan kerapatan 10 , 20, $80 \mathrm{gulma} / \mathrm{m}^{2}$ sama. Tanaman yang berkompetisi dengan Asystasia gangetica, Rottboellia exaltata dan Cyperus rotundus memiliki tinggi yang sama pada kerapatan 0 gulma $/ \mathrm{m}^{2}$. Tanaman yang berkompetisi

Tabel 4. Pengaruh interaksi jenis dan tingkat kerapatan gulma terhadap bobot kering gulma pada 6 minggu setelah tanam (MST) $\left(\mathrm{g} / 0,25 \mathrm{~m}^{2}\right)$

\begin{tabular}{|c|c|c|c|c|c|c|c|}
\hline \multirow{2}{*}{$\begin{array}{l}\text { Kerapatan } \\
\text { Gulma/m² }\end{array}$} & \multicolumn{3}{|c|}{ Asli } & \multicolumn{3}{|c|}{ Transformasi $\sqrt{ } \sqrt{ }(x+0,5)$} & \multirow{2}{*}{$\begin{array}{l}\text { BNT } \\
0,05\end{array}$} \\
\hline & A. gangetica & R. exaltata & C. rotundus & A. gangetica & R. exaltata & C. rotundus & \\
\hline 0 & 0,00 & 0,00 & 0,00 & $\begin{array}{c}0,92 \mathrm{c} \\
\text { (a) }\end{array}$ & $\begin{array}{c}0,92 \mathrm{c} \\
\text { (a) }\end{array}$ & $\begin{array}{c}0,92 \mathrm{c} \\
\text { (a) }\end{array}$ & \\
\hline 10 & 5,21 & 102,97 & 1,99 & $\begin{array}{l}1,24 \mathrm{~b} \\
\text { (b) }\end{array}$ & $\begin{array}{c}1,68 \mathrm{~b} \\
\text { (a) }\end{array}$ & $\begin{array}{c}1,10 \mathrm{~b} \\
\text { (b) }\end{array}$ & \\
\hline 20 & 9,66 & 114,93 & 3,32 & $\begin{array}{c}1,33 \mathrm{ab} \\
\text { (b) }\end{array}$ & $\begin{array}{c}1,78 \mathrm{a} \\
\text { (a) }\end{array}$ & $\begin{array}{c}1,17 \mathrm{~b} \\
\text { (b) }\end{array}$ & $(0,22)$ \\
\hline 40 & 14,25 & 137,16 & 13,77 & $\begin{array}{c}1,39 \mathrm{ab} \\
\text { (b) }\end{array}$ & $\begin{array}{l}1,84 \mathrm{a} \\
\text { (a) }\end{array}$ & $\begin{array}{l}1,38 \mathrm{a} \\
\text { (b) }\end{array}$ & \\
\hline 80 & 21,45 & 142,28 & 16,12 & $\begin{array}{c}1,47 \mathrm{a} \\
\text { (b) }\end{array}$ & $\begin{array}{c}1,85 \mathrm{a} \\
\text { (a) }\end{array}$ & $\begin{array}{c}1,42 \mathrm{a} \\
\text { (b) }\end{array}$ & \\
\hline BNT 0,05 & & & & & 0,18 & & \\
\hline
\end{tabular}

Keterangan : Angka yang diikuti oleh huruf yang sama tidak berbeda nyata berdasarkan uji BNT pada taraf 5\%, dengan tanpa tanda kurung untuk membandingkan antar kerapatan gulma dan (tanda kurung) untuk membandingkan antar jenis gulma.

Tabel 5. Pengaruh interaksi jenis dan tingkat kerapatan gulma terhadap tinggi tanaman 3 MST $(\mathrm{cm})$

\begin{tabular}{ccccc}
\hline Kerapatan Gulma/m ${ }^{2}$ & \multicolumn{3}{c}{ Tinggi Tanaman $(\mathrm{cm})$} & BNT \\
\cline { 2 - 5 } & Asystasia gangetica & Rottboellia exaltata & Cyperus rotundus & 0,05 \\
\hline 0 & $15,33 \mathrm{a}$ & $15,22 \mathrm{a}$ & $14,94 \mathrm{a}$ \\
& $(\mathrm{a})$ & $(\mathrm{a})$ & $(\mathrm{a})$ \\
10 & $14,06 \mathrm{ab}$ & $14,89 \mathrm{a}$ & $14,39 \mathrm{ab}$ \\
& $(\mathrm{b})$ & $(\mathrm{a})$ & $(\mathrm{a})$ & \\
20 & $15,17 \mathrm{ab}$ & $14,72 \mathrm{a}$ & $14,56 \mathrm{a}$ & $(0,58)$ \\
& $(\mathrm{a})$ & $(\mathrm{a})$ & $(\mathrm{b})$ & \\
40 & $14,62 \mathrm{ab}$ & $14,83 \mathrm{a}$ & $14,11 \mathrm{ab}$ & $(\mathrm{b})$ \\
& $(\mathrm{a})$ & $(\mathrm{a})$ & $13,17 \mathrm{~b}$ & $(\mathrm{~b})$ \\
\hline BNT 0,05 & $14,00 \mathrm{~b}$ & $14,44 \mathrm{a}$ & $(\mathrm{a})$ & \\
\hline
\end{tabular}

Keterangan : Angka yang diikuti oleh huruf yang sama tidak berbeda nyata berdasarkan uji BNT pada taraf 5\%, dengan tanpa tanda kurung untuk membandingkan antar kerapatan gulma dan (tanda kurung) untuk membandingkan antar jenis gulma. 
dengan Rottboellia exaltata dan Cyperus rotundus lebih tinggi dibandingkan tanaman yang berkompetisi dengan Asystasia gangetica pada kerapatan 10 gulma/ $\mathrm{m}^{2}$. Tanaman yang berkompetisi dengan Asysatsia gangetica dan Rottboellia exaltata lebih tinggi dibandingkan dengan Cyperus rotundus pada kerapatan 20-80 gulma $/ \mathrm{m}^{2}$. Menurut Kuntohartono (1980) dalam Widayat (2002), teki merupakan gulma yang memiliki sifat kompetitif kuat dengan tanaman melalui kompetisi terhadap air dan hara.

Tabel 6 menunjukkan bahwa jenis dan kerapatan gulma tidak berinteraksi dalam mempengaruhi tinggi tanaman 6 dan 9 MST. Antara jenis dan kerapatan gulma memiliki pengaruh yang samaterhadap tinggi tanaman kedelai 6 MST. Sedangkan pada tinggi tanaman 9 MST, tanaman kedelai yang berkompetisi dengan Rottboeliia exaltata lebih tinggi dibandingkan dengan tanaman yang berkompetisi dengan Asystasia gangetica dan Cyperus rotundus, namun tanaman yang berkompetisi dengan Asystasia gangetica dan Cyperus rotundussama.

Tanaman kedelai tertinggi terdapat pada kerapatan 80 gulma $/ \mathrm{m}^{2}$, namun tanaman pada kerapatan 0-40 gulma $/ \mathrm{m}^{2}$ dan $20-80$ gulma $/ \mathrm{m}^{2}$ memiliki tinggi yang sama. Hal ini diduga terjadi etiolasi pada tanaman karena adanya persaingan cahaya matahari yang mengakibatkan meningkatnya tinggi tanaman. Sugito (1999) dalam Susanto (2010) menyatakan bahwa etiolasi dipengaruhi oleh produksi dan distribusi auksin yang sangat tinggi pada bagian pucuk-pucuk tanaman sehingga tanaman tumbuh memanjang.
Jenis dan kerapatan gulma tidak berinteraksi dalam mempengaruhi bobot kering akar kedelai pada 6 MST (Tabel 6). Bobot kering akar kedelai pada perlakuan Cyperus rotundus lebih rendah dibandingkan pada perlakuan Asystasia gangetica dan Rottboellia exaltata. Bobot kering akar kedelai pada kerapatan 20 gulma/ $\mathrm{m}^{2}$ lebih tinggi dibandingkan pada kerapatan 10 gulma $/ \mathrm{m}^{2}$, tetapi bobot kering akar kedelai pada kerapatan $0,10,20,80$ gulma $/ \mathrm{m}^{2}$ dan pada kerapatan 0 , 20, 40,80 gulma/m²tidak berbeda.

Jenis dan kerapatan gulma tidak berinteraksi dalam mempengaruhi bobot kering tajuk kedelai 6 MST (Tabel 7). Jenis gulma mempengaruhi bobot kering tajuk kedelai, sedangkan kerapatan gulma tidak mempengaruhi bobot kering tajuk kedelai. Bobot kering tajuk kedelai pada perlakuan Rottboellia exaltata lebih rendah dibandingkan pada perlakuan gulma Asystasia gangetica dan Cyperus rotundus. Hal ini tidak sependapat dengan Dalimoenthe (1995) dalam Widayat (2010) yang menyatakan bahwa semakin tinggi kerapatan gulma maka penekanan gulma terhadap pertumbuhan tanaman pokok semakin tinggi.

Tabel 7 menunjukan bahwa antara jenis dan kerapatan gulma tidak berinteraksi dalam mempengaruhi jumlah polong kedelai. Jenis gulma mempengaruhi jumlah polong kedelai, sedangkan kerapatan gulma tidak mempengaruhi jumlah polong kedelai. Jumlah polong kedelai pada perlakuan Rottboellia exaltatalebih rendah dibandingkan jumlah polong kedelai pada perlakuan Asystasia gangetica dan Cyperus rotundus.

Tabel 6. Pengaruh jenis dan kerapatan gulma terhadap tinggi tanaman dan bobot kering akar tanaman kedelai.

\begin{tabular}{|c|c|c|c|}
\hline \multirow[t]{2}{*}{ Perlakuan } & \multicolumn{2}{|c|}{ Tinggi Tanaman $(\mathrm{cm})$} & \multirow{2}{*}{$\begin{array}{c}\text { Bobot kering akar pada } \\
6 \mathrm{MST} \text { (g/ tanaman) }\end{array}$} \\
\hline & $6 \mathrm{MST}$ & $9 \mathrm{MST}$ & \\
\hline \multicolumn{4}{|l|}{ Jenis Gulma : } \\
\hline Asystasia gangetica & $57,12 \mathrm{a}$ & $74,11 \mathrm{~b}$ & $6,76 \mathrm{a}$ \\
\hline Rottboellia exaltata & $57,04 \mathrm{a}$ & $77,69 \mathrm{a}$ & $6,26 \mathrm{a}$ \\
\hline Cyperus rotundus & $58,29 \mathrm{a}$ & $71,52 \mathrm{~b}$ & $4,55 \mathrm{~b}$ \\
\hline BNT0,05 & 2,85 & 2,90 & 1,21 \\
\hline \multicolumn{4}{|l|}{ Kerapatan Gulma/m²: } \\
\hline 0 & $56,76 \mathrm{a}$ & $72,17 \mathrm{~b}$ & $5,66 \mathrm{ab}$ \\
\hline 10 & $56,09 \mathrm{a}$ & $73,72 \mathrm{~b}$ & $4,75 \mathrm{~b}$ \\
\hline 20 & $58,05 \mathrm{a}$ & $74,16 \mathrm{ab}$ & 6,48 a \\
\hline 40 & $58,20 \mathrm{a}$ & $74,58 \mathrm{ab}$ & $6,22 \mathrm{ab}$ \\
\hline 80 & $58,34 \mathrm{a}$ & $77,57 \mathrm{a}$ & $6,17 \mathrm{ab}$ \\
\hline BNT0,05 & 3,69 & 3,74 & 1,56 \\
\hline
\end{tabular}

Keterangan : Angka yang diikuti oleh huruf yang sama tidak berbeda nyata berdasarkan uji BNT pada taraf $5 \%$. 
Tabel 7. Pengaruh jenis dan kerapatan gulma terhadap bobot kering tajuk dan jumlah polong pada tanaman kedelai.

\begin{tabular}{|c|c|c|c|}
\hline \multirow[t]{2}{*}{ Perlakuan } & \multicolumn{2}{|c|}{ Bobot Kering Tajuk pada 6 MST (g/ tanaman) } & \multirow{2}{*}{$\begin{array}{l}\text { Jumlah Polong Kedelai } \\
\text { (polong/tanaman) }\end{array}$} \\
\hline & Asli & Transformasi $\sqrt{ } \sqrt{ }(x+0,5)$ & \\
\hline \multicolumn{4}{|l|}{ Jenis Gulma : } \\
\hline Asystasia gangetica & 45,41 & $1,63 \mathrm{a}$ & 93,87 a \\
\hline Rottboellia exaltata & 34,87 & $1,54 \mathrm{~b}$ & $45,81 \mathrm{~b}$ \\
\hline Cyperus rotundus & 45,45 & $1,60 \mathrm{a}$ & 83,78 a \\
\hline BNT0,05 & 8,86 & 0,08 & 17,50 \\
\hline \multicolumn{4}{|l|}{ Kerapatan Gulma/m²: } \\
\hline 0 & 46,95 & $1,61 \mathrm{a}$ & 95,41 a \\
\hline 10 & 41,94 & $1,60 \mathrm{a}$ & 75,38 a \\
\hline 20 & 41,70 & $1,59 \mathrm{a}$ & 69,13 a \\
\hline 40 & 41,62 & $1,57 \mathrm{a}$ & 68,67 a \\
\hline 80 & 37,35 & $1,56 \mathrm{a}$ & 63,83 a \\
\hline BNT0,05 & 11,44 & 0,05 & 22,60 \\
\hline
\end{tabular}

Keterangan : Angka yang diikuti oleh huruf yang sama tidak berbeda nyata berdasarkan uji BNT pada taraf $5 \%$.

Jenis guma Asystasia gangetica, Rottboellia exaltata, dan Cyperus rotundus memiliki pengaruh yang berbeda terhadap pertumbuhan dan produksi kedelai. Rottboellia exaltata memiliki daya saing yang lebih tinggi dibandingkan Asystasia gangetica dan Cyperus rotundus sehingga mampu menurunkan pertumbuhan dan produksi kedelai. Perlu dilakukan pengendalian terhadap Rottboellia exaltata pada saat awal tanam dan saat fase generatif.

\section{KESIMPULAN}

Gulma Rottboellia exaltata menurunkan jumlah daun 9 MST, bobot kering tajuk tanaman dan jumlah polong kedelai, Cyperus rotundus menurunkan tinggi tanaman 9 MST dan bobot kering akar tanaman, dan Asystasia gangetica menurunkan terhadap tinggi tanaman 9 MST. Kehadiran ketiga jenis gulma tersebut pada kerapatan $10 \mathrm{gulma} / \mathrm{m}^{2}$ sudah mampu menekan tinggi kedelai 9 MST dan bobot kering akar kedelai. Antara jenis dan kerapatan gulma saling berpengaruh sehingga dapat menekan tinggi tanaman kedelai 3 MST.

\section{DAFTAR PUSTAKA}

Adisarwanto, T. dan R. Wudianto. 1999. Meningkatkan Hasil Panen Kedelai di Lahan Sawah-Kering-Pasang Surut. Penebar Swadaya. Bogor. 86 hal.
Moenandir, J. 1993. Persaingan Tanaman Budidaya dengan Gulma. PT Raja Grafindo Persada. Jakarta.

Pasau, P., P. Yudono, dan A. Syukur. 2008. Pergeseran komposisi gulma pada perbedaan proporsi kerapatan jagung dan kacang tanah dalam tumpangsari pada Regosol Sleman. Jurnal Ilmu Pertanian. 16(2): 60-78.

Purwanto dan T. Agustono. 2010. Kajian fisiologi tanaman kedelai pada kondisi cekaman kekeringan dan berbagai kepadatan gulma teki. Jurnal Agrosains. 12(1): 24-28.

Sastroutomo, S.S. 1990. Ekologi Gulma. PT Gramedia Pustaka Utama. Jakarta. 217 hal.

Sembodo, D. R. J. 2010. Gulma dan Pengolahannya. Penerbit Graha Ilmu. Yogyakarta.

Susanto, G.W.A. 2010. Pengaruh naungan buatan terhadap karakter fenotipik enam genotipe kedelai. Jurnal Agrivigor. 9(3): 293-304.

Tjitrosoedirdjo, S. I., H. Utomo dan J. Wiroatmojo (Ed). 1984. Pengelolaan Gulma di Perkebunan. PT Gramedia. Jakarta. 210 hal.

Yeheskiel.2006.Periode Kritis Tanaman Kedelai terhadap Kompetisi Gulma pada Beberapa Jarak Tanam di Lahan Alang-alang. Skripsi. Institut Pertanian Bogor. Bogor. 
Yunita. 2012. Kompetisi Lima Jenis Gulma dan Kerapatan Gulma pada Pertumbuhan dan Produksi Tanaman Kedelai. Skripsi. Fakultas Pertanian Universitas Lampung. Bandar Lampung.

Widayat, D. 2002. Kemampuan Berkompetisi Kedelai (Glycine max [L.] Merill) Kacang Tanah (Arachis hypogaea) dan Kacang Hijau (Vigna radiata) terhadap Teki (Cyperus rotundus). Jurnal Bionatura. 4(2): 118-128.
Widyatama, C. E., Tohari dan R, Regomulyo. 2010. Periode Kritis Kedelai Hitam (Glycine max (L.) Merill) Terhadap Gulma. Jurnal Produksi Tanaman. $10 \mathrm{Hal}$. 